\title{
Beneficial Effects of Natural Bioactive Compounds from Hibiscus sabdariffa L. on Obesity
}

\author{
Oyindamola Vivian Ojulari ${ }^{1}$, Seul Gi Lee ${ }^{1}$ and Ju-Ock Nam ${ }^{1,2, *}$ \\ 1 Department of Food Science and Biotechnology, Kyungpook National University, Daegu 41566, Korea; \\ hoyeendahmolar@gmail.com (O.V.O.); lsg100479@naver.com (S.G.L.) \\ 2 Institute of Agricultural Science \& Technology, Kyungpook National University, Daegu 41566, Korea \\ * Correspondence: namjo@knu.ac.kr; Tel.: +82-53-950-7760
}

Academic Editor: Min-Hsiung Pan

Received: 29 November 2018; Accepted: 8 January 2019; Published: 8 January 2019

\begin{abstract}
Obesity is a condition associated with the accumulation of excess fat in the body, energy imbalance, lipogenesis, etc., which increases adipose tissue mass through adipogenesis and poses a health risk. Its prevalence has become an economic burden to the health care system and the world at large. One of the alternatives to tackling obesity involves the use of bioactive compounds. We critically examined the effects of Hibiscus sabdariffa extract (HSE) on various parameters associated with the development of obesity such as; the effect of HSE on body weight, the effect of HSE on lipid accumulation, cholesterol metabolism and plasma parameters, the inhibitory effect of HSE on pancreatic lipase, and the effect of HSE on adipocyte differentiation/adipogenesis. This review has gathered reports on the various anti-obesity effects of $H$. sabdariffa bioactive compounds in cell and animal models, as well as in humans. Available toxicology information on the consumption of H. sabdariffa revealed that its toxicity is dose-dependent and may cause an adverse effect when administered over a long period of time. Reports have shown that $H$. sabdariffa derived bioactive compounds are potent in the treatment of obesity with an evident reduction in body weight, inhibition of lipid accumulation and suppression of adipogenesis through the PPAR $\gamma$ pathway and other transcriptional factors.
\end{abstract}

Keywords: adipogenesis; bioactive compounds; fat accumulation; Hibiscus sabdariffa; lipase inhibition

\section{Introduction}

Obesity is a major public health problem associated with an increased incidence of metabolic diseases like type 2 diabetes, high blood pressure, heart disease, liver disease, kidney disease, gallbladder disease, and certain types of cancer [1]. The underlying cause of obesity can be attributed to the diet, genetic disorders, sedentary lifestyle, and psychological factors. The imbalance between energy intake and expenditure also causes the buildup of excess adipose tissue [2].

Several approaches have been made towards combating obesity, which include the clinical approach like surgical and lifestyle changes, exercising to induce weight loss and reduce fat accumulation, dietary approaches like caloric restriction, ketogenic diet and pharmacological approaches in which weight loss drugs have been developed. However, this approach has been found to be seasonal and not long-lasting [3], as it eventually creates a yo-yo effect. For a more lasting solution, research is leaning towards the use of bioactive compounds in plant materials as a novel therapy to combat obesity and its related diseases.

Recently, natural bioactive compounds such as flavonoids and phenols have been reported to be effective in the treatment of obesity [4-7]. Bioactive compounds in edible plants such as epigallocatechin gallate (EGCG) from green tea, nobiletin from citrus peel, curcumin from turmeric, resveratrol, pterostilbene from berries and anthocyanins from $\mathrm{H}$. sabdariffa have been reported for their anti-obesity 
potential in both in-vivo and in-vitro studies [8-12]. H. sabdariffa also known as Roselle has a long history of usage as a beverage and folk medicine in places such as Thailand and, Nigeria, China, and India [13-15].

Studies on the phytochemical properties of H. sabdariffa showed that it has several health benefits and could be used as a potent material for the therapeutic treatment of various diseases $[16,17]$. Its chemical composition also showed that the therapeutic potency of $H$. sabdariffa could be traced to the presence of bioactive compounds. Bioactive compounds such as flavonoids (quercetin, luteolin, and its glycoside); chlorogenic acid, gossypetin, hibiscetin, phenols, some phenolic acids, anthocyanins such as delphinidin-3-sambubioside and cyanidin-3-sambubioside were detected as the main components in the aqueous extract of $H$. sabdariffa [18]. These bioactive compounds together or alone have been reported in many studies to possess potent antioxidant, anti-inflammatory, anti-carcinogenic effects and may also help control diabetes, prevent cardiovascular disease and obesity [19-26].

Reviews are available on the use of $H$. sabdariffa. However, reviews on H. sabdariffa and its bioactive compounds in relation to obesity are still insufficient. Previous reviews have focused on the phytochemical, pharmacological and toxicological properties of $H$. sabdariffa. $[15,17,27,28]$. Other comprehensive reviews documented by Wahabi et al., [29], Carjaval-Zarabal., [30], Hopkins et al., [31] Serban et al., [32] and Walton et al., [33] revealed the effect of $H$. sabdariffa in the treatment of hypertension hyperlipidemia and apoptosis. Its traditional use, nutritional composition, bioactive constituents, health benefits, and therapeutic use were examined by Riaz and Chopra [17], Singh et al., [34], and Ismail et al., [35]. A review by Herranz-Lopez et al., [36] focused on the multi-targeted molecular effect of hibiscus polyphenols on obesity management, Aziz et al., [37] has also reviewed its effect on serum lipids. Therefore, this present review takes into consideration available reports on the beneficial effects as well as toxicology of natural bioactive compounds in $H$. sabdariffa in relation to obesity therapy.

\section{Natural Bioactive Compounds in H. sabdariffa}

Bioactive compounds are compounds produced by plants that have pharmacological or toxicological effects in man and animals [38]. Various natural compounds have been identified to influence weight loss, fat accumulation, and avert diet-induced obesity. Hence, these products have been extensively consumed for the treatment of abdominal obesity and overweight $[4,39,40]$.

Many studies have shown the calyxes of $H$. sabdariffa to contain various compounds. The main bioactive compounds generally believed to be the active constituents responsible for the therapeutic effects of $H$. sabdariffa are organic acids, anthocyanins, flavonoids and phenolic acids, as seen in Table 1 and Figure 1 which shows their chemical structural formula.

Table 1. Major bioactive compound in H. sabdariffa.

\begin{tabular}{ccc}
\hline \multicolumn{1}{c}{ Bioactives } & Chemical Formula & Studies on Obesity \\
\hline Organic acids & & \\
\hline $\begin{array}{c}\text { Hydroxycitric acid } \\
\text { Hibiscus acid } \\
\text { Dimethyl hibiscus acid }\end{array}$ & $\mathrm{C}_{6} \mathrm{H}_{8} \mathrm{O}_{8}$ & {$[41,42]$} \\
$\mathrm{C}_{6} \mathrm{H}_{6} \mathrm{O}_{7}$ & - \\
\hline Anthocyanins & $\mathrm{C}_{8} \mathrm{H}_{10} \mathrm{O}_{7}$ & - \\
\hline Delphinidin-3-sambubioside (hibiscin) & & - \\
Cyanidin-3-sambubioside (gossypicyanin) & $\mathrm{C}_{26} \mathrm{H}_{30} \mathrm{O}_{16}$ & - \\
Cyanidin-3,5-diglucoside & $\mathrm{C}_{26} \mathrm{H}_{30} \mathrm{O}_{15}$ & - \\
Delphinidin (anthocyanidin) & $\mathrm{C}_{26} \mathrm{H}_{30} \mathrm{O}_{15}$ & {$[43]$} \\
\hline Flavonoids & $\mathrm{C}_{15} \mathrm{H}_{11} \mathrm{O}_{7}$ & - \\
\hline Hibiscitrin (hibiscetin-3-glucoside) & & - \\
Gossypitrin & & {$[44,45]$} \\
Quercetin & $\mathrm{C}_{21} \mathrm{H}_{20} \mathrm{O}_{14}$ & {$[46]$} \\
\hline
\end{tabular}


Table 1. Cont.

\begin{tabular}{|c|c|c|}
\hline Bioactives & Chemical Formula & Studies on Obesity \\
\hline \multicolumn{3}{|l|}{ Phenolic acid } \\
\hline Chlorogenic acid & $\mathrm{C}_{16} \mathrm{H}_{18} \mathrm{O}_{9}$ & {$[47,48]$} \\
\hline Protocatechuic acid & $\mathrm{C}_{7} \mathrm{H}_{6} \mathrm{O}_{4}$ & [49] \\
\hline Ellagic acid & $\mathrm{C}_{14} \mathrm{H}_{6} \mathrm{O}_{8}$ & {$[50,51]$} \\
\hline P-Coumaric acid & $\mathrm{C}_{9} \mathrm{H}_{8} \mathrm{O}_{3}$ & [52] \\
\hline Ferulic acid & $\mathrm{C}_{10} \mathrm{H}_{10} \mathrm{O}_{4}$ & {$[53,54]$} \\
\hline Caffeic acid & $\mathrm{C}_{9} \mathrm{H}_{8} \mathrm{O}$ & {$[55,56]$} \\
\hline
\end{tabular}

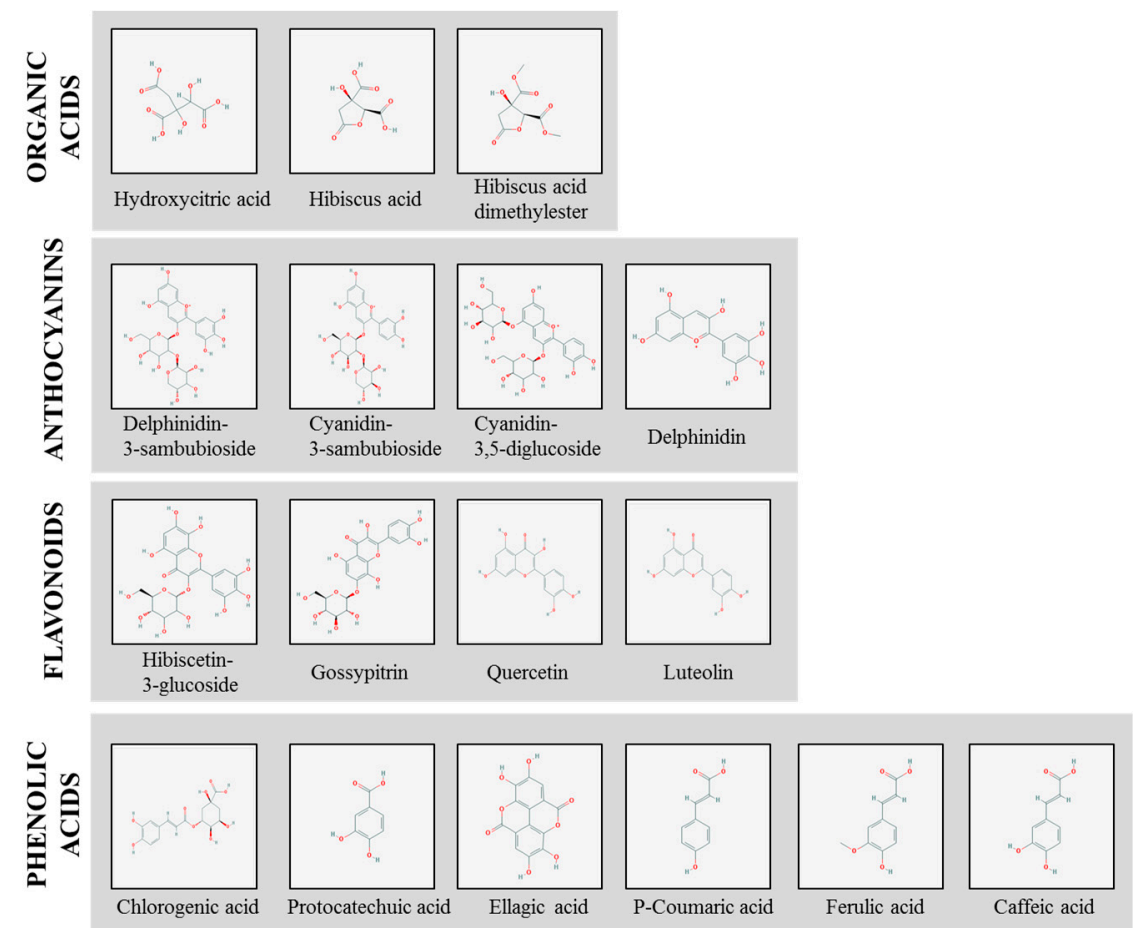

Figure 1. Chemical structural formula of major bioactive compounds in H. sabdariffa.

Different studies (as shown in Table 2) have attributed the anti-obesogenic potential of $H$. sabdariffa extract (HSE) in obesity treatment to one or more specific compounds that it contains $[11,57]$. While some authors reported polyphenols $[8,20,58]$ and anthocyanin $[9,10]$ as the main active component in $\mathrm{H}$. sabdariffa, another group of authors concluded in their report that other organic acids (hibiscus, dimethyl hibiscus and, hydroxycitric acids) contained in $H$. sabdariffa were responsible for the beneficial effects observed in their study [57]. The non-conformity of these reports could be due to the solvent used for extraction. Morales-Luna et al., [57] who compared both aqueous and methanolic extract of white and red varieties of $H$. sabdariffa, reported that aqueous extract of both varieties showed higher organic acid content compared to the methanolic extract, while polyphenols anthocyanin and flavonoids were higher in methanolic extract. However, some authors have suggested aqueous or aquueous-ethanolic solvent to be preferred for the extraction of anthocyanins, flavonoids and polyphenols from $H$. sabdariffa calyes [11,58-60]. Various reports on the effects of these compounds on obesity treatment will be highlighted under different sections of this review. 
Table 2. Studies on H. sabdariffa bioactive compounds and their anti-obesity effects.

\begin{tabular}{|c|c|c|c|c|c|}
\hline Subject & Extraction Solvent & Effective Dose & Species & Observed Effect(s) & References \\
\hline \multirow{2}{*}{ Mouse } & Aqueous & $33.64 \mathrm{mg} / \mathrm{kg}$ & Swiss Webste (CFW) & $\begin{array}{l}\text { Suppressed body weight gain in Ob/MSG mice by } 9.6 \% \text { and reduces } \\
\text { glycaemia }\end{array}$ & [9] \\
\hline & Aqueous & $33 \mathrm{mg} / \mathrm{kg}$ & C57BL/6NHsd & $\begin{array}{l}\text { Reduced fat tissue accumulation, normalized the glycemic index as well as } \\
\text { reduced dyslipidemia }\end{array}$ & [61] \\
\hline \multirow{6}{*}{ Rat } & Methanol & $100 \mathrm{mg} / \mathrm{kg}, 200 \mathrm{mg} / \mathrm{kg}$ & Sprague-Dawley rats & $\begin{array}{l}\text { Significantly reduced the plasma level of triacylglycerol cholesterol, and } \\
\text { LDL/HDL risk ratio }\end{array}$ & {$[62]$} \\
\hline & Methanol & $200 \mathrm{mg} / \mathrm{kg}$ & Sprague-Dawley rats & $\begin{array}{l}\text { HPE inhibited fat deposition, hyperglycemia, serum advanced glycation } \\
\text { end-products (AGE) }\end{array}$ & {$[63]$} \\
\hline & $\begin{array}{l}\text { Aqueous and } \\
\text { Methanol }\end{array}$ & $3 \%$ of $750 \mathrm{mg}(22.5 \mathrm{mg})$ & Wistar Rats & $\begin{array}{c}\text { Prevented increase in body weight and decreased adipocytes hyperplasia } \\
\text { on rats fed a hypercaloric diet }\end{array}$ & [57] \\
\hline & Ethanol & $5 \%, 10 \%, 15 \%(v / v)$ & Sprague-Dawley rats & $\begin{array}{c}\text { Prevented increase in body weight, triglyceride, LDL and total lipids were } \\
\text { lowered }\end{array}$ & [12] \\
\hline & Aqueous & $100 \mathrm{mg} / \mathrm{kg}$ & Sprague-Dawley rats & $\begin{array}{l}\text { Attenuated body weight gain, plasma leptin, cholesterol, triglycerol, LDL } \\
\text { and systolic blood pressure }\end{array}$ & {$[64]$} \\
\hline & Aqueous & $500 \mathrm{mg} / \mathrm{kg}$ & Sprague-Dawley rats & Prevented the hypercholesterolemia induced by dietary fructose & [65] \\
\hline \multirow{2}{*}{ Human } & Aqueous & $1 \mathrm{~g}$ HSE capsule-dose & In vivo (human trial) & Decreased serum FFA level of the HSE group and improved liver steatosis & [66] \\
\hline & - & 100mg (Capsule) & In vivo (clinical study) & $\begin{array}{l}\text { Patients with metabolic syndrome showed a significant reduction in total } \\
\text { cholesterol and glucose level, with increased HDL level }\end{array}$ & [67] \\
\hline \multirow{4}{*}{ Cultured cells } & Methanol & 0.25 or $0.5 \mathrm{mg} / \mathrm{mL}$ & 3T3-L1 pre-adipocytes cell & $\begin{array}{l}\text { Suppressed differentiation and increased number of apoptotic cells in } \\
\text { mature adipocytes }\end{array}$ & {$[8]$} \\
\hline & Aqueous & $2 \mathrm{mg} / \mathrm{mL}$ & 3T3-L1 pre-adipocytes cell & $\begin{array}{c}\text { Inhibition of lipid accumulation by reducing intracellular lipid droplet } \\
\text { during adipogenesis }\end{array}$ & {$[10]$} \\
\hline & Aqueous & $100 \mathrm{mg} / \mathrm{mL}$ & 3T3-L1 pre-adipocytes cell & $\begin{array}{l}\text { Reduced the expression of major adipogenic transcription factors } \\
\text { including PPAR } \gamma \text { and C/EBP } \alpha \text { that regulate adipogenesis }\end{array}$ & [68] \\
\hline & Aqueous and ethanol & $\begin{array}{l}500 \mu \mathrm{g} / \mathrm{mL} \text { aqueous } \\
\text { extract and ethanol } \\
\text { extract } 10 \mu \mathrm{g} / \mathrm{mL}\end{array}$ & 3T3-L1 pre-adipocytes & $\begin{array}{c}\text { Inhibited lipid accumulation and adipogenic differentiation of } \\
\text { pre-adipocytes }\end{array}$ & [58] \\
\hline
\end{tabular}




\section{Effect of H. sabdariffa Extract (HSE) on Obesity}

\subsection{Effect of HSE on Body Weight}

As aforementioned, obesity can be characterized by chronic energy imbalance and excessive body weight $[2,69]$. This disruption in energy homeostasis results in abnormal adipocyte differentiation, which is characterized by hyperplasia and hypertrophy of adipocytes [70]. The potentiality of polyphenols in $\mathrm{H}$. sabdariffa to regulate energy metabolism and its beneficial effect on lipid management and weight loss as studied by several authors will be examined in this section.

Villalpando-Arteaga et al. [61] reported a reduction in body weight in relation to inhibition of fat accumulation of obese C57BL/6NHsd mice after treating with $33 \mathrm{mg} / \mathrm{kg}$ three times a week for 8 weeks. Impressively, Alarcon-Aguilar et al., [9] recorded a 9.6\% decrease in body weight of obese Monosodium glutamate (MSG) mice with daily administration of $33.64 \mathrm{mg} / \mathrm{kg} /$ day for 8 weeks. A significant shift in body weight was noticed from the 7th week, which was attributed to a reduction in food with a consequent increase in liquid intake.

Herrara-Arellano et al., [25] who also reported a similar observation, attributed this result to the diuretic effect of $H$. sabdariffa. In spite of these observations, the author suggested that further long-term toxicity studies should be performed on this plant, especially since the previous study by Akindahunsi and Olaleye [71] have identified in their study that prolonged usage of this extract at a 15-dose level caused liver injury while the effect was mild at small dose levels (1-10). Carvajal-Zarrabal et al., [12] also reported that HSE administered at concentrations of $5 \%$ to $15 \%$ was effective in body weight reduction at intermediate and greater concentrations of $10 \%$ and $15 \%$ used in their experiment. In vitro and in vivo studies showed that HSE (or tea) inhibited the activity of a-amylase, blocking sugars and starch absorption, which may assist in weight loss [72,73]. Overall, in most studies, the ability of HSE to reduce body weight was attributed to H. sabdariffa polyphenols and flavonoids, through the inhibition of fat accumulation $[9,61]$.

\subsection{Effect of HSE on Lipid Accumulation, Cholesterol Metabolism and Plasma Parameters}

Other factors are also involved in causing the onset of obesity. The major mark of obesity is abnormal or excessive fat accumulation in adipose tissue. The amount of excess fat in absolute terms, and its distribution in the body-either around the waist and trunk (abdominal, central or android obesity) or peripherally around the body (gynoid obesity) have important health implications [74]. The effect of $H$. sabdariffa on weight loss in early studies prompted further studies on its effect on lipid profile. Quite a number of studies have emphasized HSE as having an effect on inhibiting and/or reducing fat accumulation.

Bioactive compounds (polyphenolic and flavonoids) in H. sabdariffa have been reported to decrease oxysterols (a derivative cholesterol) in bile acid metabolism and block lipid accumulation in the liver [75]. In a study conducted by Carvajal et al., [12] on the modulation of fat absorption in rats by HSE, it was reported that HSE modulated fat absorption by increasing palmitic acid excretion in feces, accompanied by a decrease in triglycerides and cholesterol levels, including low-density lipoproteins (LDL) cholesterol. Another study carried out to evaluate the effects of HSE powder on the lipid profiles of individuals with and without metabolic syndrome (MS) showed that HSE significantly reduced glucose and total cholesterol levels, increased HDL levels, and triglycerides/HDL ratio in patients with MS [76]. In cholesterol-fed rabbits and high fructose-fed rats, HSE also decreased the number of oxidized LDL positive foam cells and total cholesterol and triglycerides concentrations in plasma [67]. According to Morales-Luna et al., [57], it was reported that $22.5 \mathrm{mg}$ aqueous HSE of the white variety of Roselle prevented the increase in body weight of rats that were fed a high-fat fructose diet.

A more recent study investigated the effect of HSE in the reduction of fat tissue accumulation in high fat diet-induced obese C57BL/6NHsd mice [61]. A high-fat diet (HFD), along with reduced physical activity, induces excessive storage of triglycerides in adipocytes that leads to hypertrophy of the adipose tissue (AT). The study reported that HSE greatly diminished the accumulation of fat in the 
cytoplasm of hepatocytes. A significant reduction $(p<0.05)$ was observed in the gene expression of both transcription factors PPAR $\gamma$ and SREBP-1c in obese mice supplemented with HSE compared to obese mice. These authors claimed that HSE regulated the lipid homeostasis through SREBP-1c and PPAR $\gamma$ inhibition by blocking the increase of IL-1, TNF- $\alpha$ mRNA and lipoperoxidation and increased catalase mRNA; counteracting liver damage in an agonist-dependent manner. Hence, they concluded that HSE possesses an anti-steatogenic effect in the liver besides the anti-lipidemic and anti-obesogenic effects in the HFD-induced obese mouse model. Considering that fat accumulation is highly associated with obesity, accumulations of fat in organs have been a major concern in obesity management.

In liver steatosis, the anti-steatogenic effect of HSE on fatty liver (caused by fat accumulation in the liver) was recently conducted on humans. A clinical study conducted on patients with fatty liver within the age of 18-65 revealed that 2 HSE capsule-dose $(1 \mathrm{~g})$ after meals, 3 times a day significantly reduced the level of serum free fatty acid (FFA), exerting a beneficial effect on metabolic regulation, while improving the liver steatosis. However, this study observed no significant difference in the lipid profile except for FFA [66]. Furthermore, it was inferred in this study that polyphenol was mainly responsible for the clinical effect of HSE capsule and hence an increase in its dose could be more effective. A dose-dependent decrease in triglycerides levels, fatty acid concentrations and cholesterol contents of plasma lipids and liver lipids were observed in an in-vivo study of high-fat induced male Syrian hamsters fed with HSE [8]. HSE effectively inhibited lipid accumulation from fat-feeding and decrease the cholesterol in plasma and organs (liver) [8]. Affirmatively, these authors also attributed the effects observed in HSE-fed hamsters to the presence of polyphenols in HSE. Clinical studies on patients with metabolic syndrome, an obesity-associated disorder, further supported arguments of previous reports that polyphenols may be responsible for the therapeutic effect in HSE [20].

Based on these studies, it can be inferred that the presence of natural bioactive compounds such as polyphenols, flavonoids, and organic acids in HSE could be used as a preventive therapy in combating fat-induced obesity.

\subsection{Inhibitory Effect of HSE on Pancreatic Lipase}

Another strategy that has been proposed for the treatment of obesity is to inhibit pancreatic lipase, which consequently decreases lipid absorption in the intestine [77]. The underlying concept is that for any dietary fat being absorbed in the human intestine, the fat should be broken down enzymatically by the action of pancreatic lipase [78]. Pancreatic lipase activity is therefore widely considered as one of the most important indicators for the determination of the anti-obesity potential of natural products [79]. Orlistat, a potent, specific, and irreversible inhibitor of pancreatic and gastric lipases, is a weight-loss agent with a novel mechanism of action for the treatment of obesity. It inhibits gastric and pancreatic lipases in the lumen of the gastrointestinal tract to decrease systemic absorption $(30 \%)$ of dietary fat [80]. However side effects such as diarrhea, fecal incontinence, flatulence, bloating and dyspepsia are commonly developed [11]. Due to these adverse effects, there has been a long-standing interest in discovering well-tolerated natural inhibitors for nutrient digestion and absorption.

The potential inhibitory activity against pancreatic lipase was also reported by examining the effect of HSE on fat absorption-excretion and body weight in rats [12]. Thus, continuous administration of $H$. sabdariffa polyphenols might improve obesity-related metabolic disorders in a similar manner to orlistat [36]. While this action may be viewed as a potential strategy in obesity management, its mechanism in obesity therapy is yet to be explored.

\subsection{Effect of HSE on Adipocyte Differentiation (Adipogenesis)}

Adipogenesis is the process by which cells differentiate into adipocytes. This process involves the conversion of preadipocytes into mature adipocytes with intracellular lipid accumulation [81]. Adipocytes are cells that primarily compose adipose tissue, specialized in storing energy as fat [82]. They play an important role in regulating adipokine secretion which promotes adipogenesis. Therefore, 
understanding the molecular mechanisms that regulate adipogenesis is important for exploring anti-obesity therapy [83].

Adipocyte differentiation is a critical phenomenon in the development and progression of obesity [84]. Adipocyte differentiation has been reported to be mainly mediated by the transcription factors PPAR $\gamma$ and $\mathrm{C} / \mathrm{EBP} \alpha$ [81]. These adipogenic transcription factors that are implicated to activate a number of genes induced during adipocyte differentiation is a master regulator of adipogenesis [85-87]. Hence, a down-regulation of PPAR $\gamma$ and C/EBP $\alpha$ has been viewed as a strategy to obstruct adipogenesis in adipocytes. Several studies have reported that extract of various medicinal plants attenuates expression of PPAR $\gamma$ and $C / E B P \alpha[10,61,88-91]$.

So far, only a few studies have reported and confirmed the effect of HSE on adipocyte differentiation. Kim et al., [68] first reported the effect of HSE treatment on adipocyte differentiation from 3T3-L1 preadipocytes and found that HSE blocked adipogenesis, possibly mediated through the suppression of adipogenic transcription factor expression. HSE treatment $(100 \mathrm{mg} / \mathrm{mL})$ inhibited the expression of major adipogenic transcription factors PPAR- $\gamma$ and C/EBP- $\alpha$, nuclear hormone receptors that regulate adipogenesis during differentiation. The authors further stated that this inhibitory effect of HSE on the transcription factors was target specific [68]. Further studies by Kim et al. [10], also confirmed that HSE can inhibit the adipogenic transcription factors by blocking the MAPK-mediated signaling pathway during adipocyte differentiation. They reported that HSE significantly decreased the mRNA levels of leptin (a hormone predominantly made by adipose cells that helps to regulate energy balance) during differentiation. Hence, suggesting that the effect of HSE on adipocyte differentiation was also mediated by the regulation of leptin [10].

A recent study performed on 3T3-L1 pre-adipocytes cells revealed that $H$. sabdariffa aqueous extract and $H$. sabdariffa polyphenols at concentrations $500 \mu \mathrm{g} / \mathrm{mL}$ and $10 \mu \mathrm{g} / \mathrm{mL}$ significantly inhibited adipogenic differentiation of pre-adipocytes [58]. These authors concluded that polyphenols contained in H. sabdariffa are mainly accountable for its effect on adipogenesis. Kao et al. [8], also showed that $H$. sabdariffa polyphenolic extract (HPE) was more efficient in suppressing adipogenesis than HSE as markers of adipocyte differentiation, while SREBP 1 was found to decrease in a concentration-dependent manner following treatment with both HSE and HPE. The authors reported in their study that after inducing maturation of preadipocyte, HPE suppressed the adipogenesis of mature adipocyte cells. This corroborates with the previously reported findings that polyphenols are the major active components in HSE that are responsible for its anti-obesogenic effect.

Based on the literature reviewed, $H$. sabdariff's natural bioactive compounds such as polyphenols have shown good potential in modulating PPAR $\gamma$ and other transcriptional activities as shown in Figure 2, which makes it a potential therapy to inhibit adipogenesis and hence, combat obesity. 


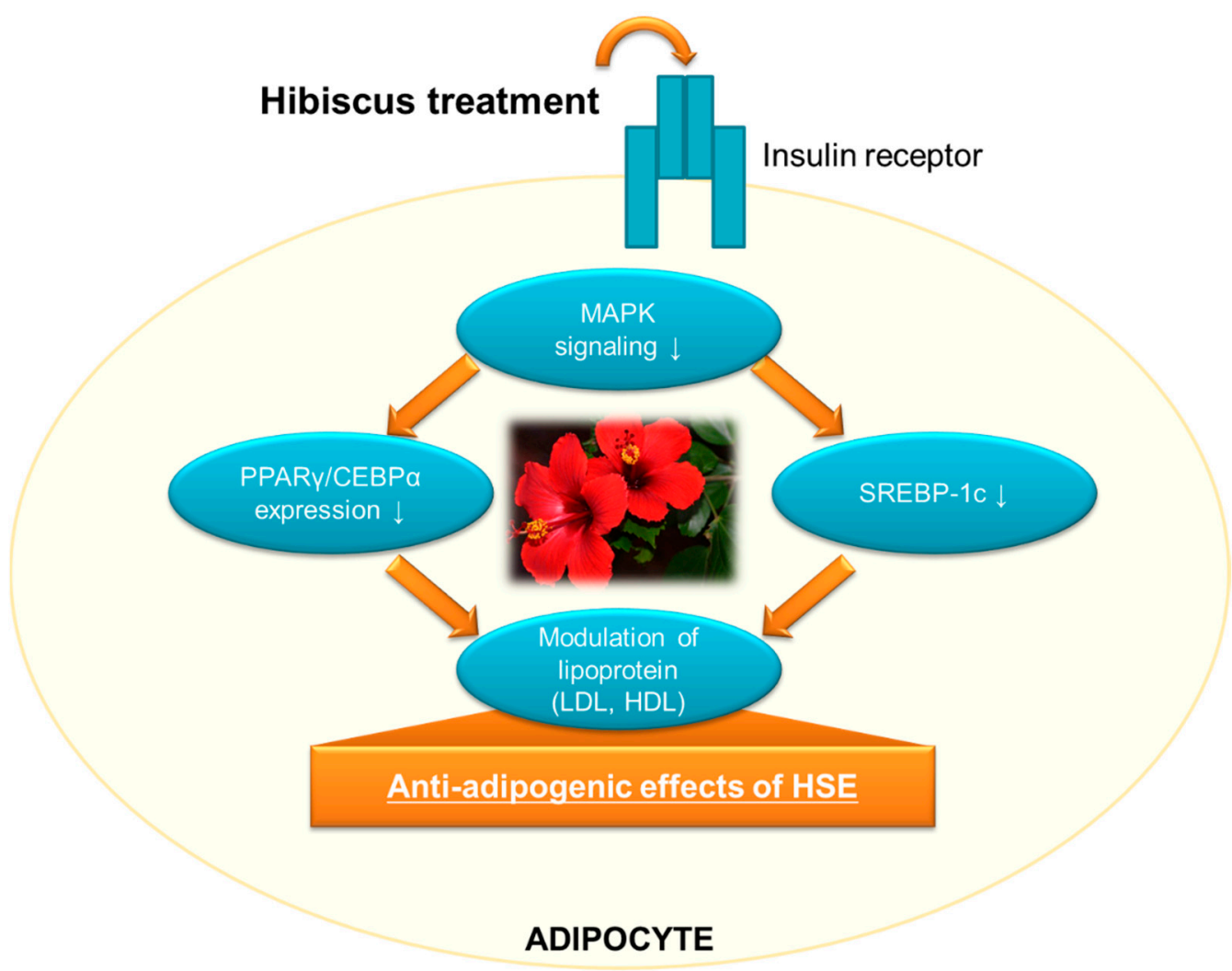

Figure 2. Anti-adipogenic effects on HSE through different pathways.

\section{Toxicity of $H$. sabdariffa}

Apart from the various beneficial effects of $\mathrm{H}$ sabdariffa, its safety for consumption as food or drug should also be addressed. Hibiscus sabdariffa have been reported to have a low degree of acute toxicity (Onyenekwe et al., [92]; Orisakwe et al., [93]; Ndu et al., [94]; Hopkins et al., [31]. Pharmacological studies identified that its co-administration with drugs may lead to increased side effects, toxicity or therapeutic failure (Johnson et al., 2013; Kolawole \& Maduenyi, [95]; Ndu et al., [94].

Jabeur et al., [60] in their study used porcine liver primary cell culture (PLP2) to evaluate the hepatotoxicity of the HSE. They reported that no toxicity was observed in HSE up to the maximal tested concentration of $400 \mu \mathrm{g} / \mathrm{mL}$. Non-cytotoxicity of Hibiscus sabdariffa aqueous extract has also been observed on normal fetal foreskin fibroblast (HFFF) cells (Khaghani et al., [96]. The doses of 250-1000 mg/kg/day HSE administered for 30days did not show any harmful effects organs system like liver, kidney, blood system, electrolytes, lipid, and carbohydrate metabolism of Wistar rats (Prommetta et al., 2006). However, high doses and prolonged usage have been reported to cause liver injury (Akindahunsi \& Olaleye [71]; Fakeye et al., [97]). A high dose (300-2000 mg/kg) of HSE for 3 months was reported to have an adverse effect on liver enzymes, indicating that at very high doses, HSE could be hepatotoxic (Fakeye et al., [97]. Contrary to the previous statement, animal studies using male Wistar albino rats reported that high doses administration of HSE $(4600 \mathrm{mg} / \mathrm{kg})$ for 3 months did not cause toxic reactions, although negative effects on testes and sperm count were found (Orisakwe et al., [93]. Also, according to Onyenekwe et al., [92], no death was observed in mice fed with high doses of HSE $(5000 \mathrm{mg} / \mathrm{kg}$ ) for 14 days. Thus, these authors estimated the lethal dose to be greater than $5000 \mathrm{mg} / \mathrm{kg}$.

\section{Conclusion}

Obesity is a common but often underrated condition that is globally considered to be a major public health concern that contributes significantly to the rate of morbidity and death. This review 
has shown the effectiveness of HSE on obesity-related parameters according to different experimental designs employed in various studies reviewed. Results have consistently reported that HSE consumption reduces body weight, lipid accumulation and total cholesterol metabolism in both animal and human studies. Its effectiveness in inhibiting pancreatic lipase and on adipocyte differentiation has also been frequently reported, thus confirming its therapeutic potential in obesity management.

H. sabdariffa extracts are generally considered to have a low degree of toxicity. However, some studies revealed that $H$. sabdariffa consumption at high doses may have some adverse effects. Hence more animal and clinical studies are required to determine safe doses of $H$. sabdariffa to balance the therapeutic and toxicological effects. Since clinical and animal studies have shown $H$. sabdariffa bioactive compounds to be effective in combating obesity, its regulated use as an active ingredient incorporated into diets at safe dosage is suggested.

The inconsistency of available studies on specific bioactive compounds responsible for anti-obesogenic properties of $H$. sabdariffa, as well as effective and safe doses, makes it necessary to carry out further studies for a more unanimous report.

Author Contributions: Conceptualization, O.V.O, S.G.L, and J.-O.N.; Writing-original draft, O.V.O; Review \& Editing, O.V.O and S.G.L; Supervision, J.-O.N. All authors have read the manuscript before submission.

Conflicts of Interest: The authors declare that there are no conflicts of interest.

\section{Abbreviations}

$\begin{array}{ll}\text { Adipose tissue } & \text { AT } \\ \text { Epigallocatechin gallate } & \text { EGCG } \\ \text { Free fatty acid } & \text { FFA } \\ \text { High-density lipoproteins } & \text { HDL } \\ \text { Hibiscus sabdariffa extract } & \text { HSE } \\ \text { Interleukin-1 } & \text { IL-1 } \\ \text { Low-density lipoproteins } & \text { LDL } \\ \text { Messenger RNA } & \text { mRNA } \\ \text { Metabolic syndrome } & \text { MS } \\ \text { Not specified } & \text { NS } \\ \text { Peroxisome Proliferator-activated Receptor } \gamma & \text { PPAR } \gamma \\ \text { Sterol regulatory element-binding protein } & \text { SREBP-1c } \\ \text { Tumor necrosis factor } \alpha & \text { TNF- } \alpha\end{array}$

\section{References}

1. Laura Segal, J.; Martin, A. The State of Obesity: Better Policies for a Healthier America 2016; Robert Wood Johnson Foundation: Princeton, NJ, USA, 2016.

2. Lee, S.G.; Lee, Y.J.; Jang, M.H.; Kwon, T.R.; Nam, J.O. Panax ginseng Leaf Extracts Exert Anti-Obesity Effects in High-Fat Diet-Induced Obese Rats. Nutrients 2017, 9, 999. [CrossRef] [PubMed]

3. Annamalai, S.; Mohanam, L.; Alwin, D.; Prabhu, V. Effect of combination therapy of melatonin and orlistat on high fat diet induced changes in lipid profiles and liver function parameters in serum of rats. Obes. Med. 2016, 2, 41-45. [CrossRef]

4. Sharmila, B.G.; Kumar, G.; Rajasekara, P.M. Cholesterol lowering activity of the aqueous fruit extract of Trichosanthes dioica Roxb. in normal and streptozotocin diabetic rats. J. Clin. Diagn. Res. 2007, 1, 561-569.

5. Abdul Rahman, H.; Saari, N.; Abas, F.; Ismail, A.; Mumtaz, M.W.; Abdul Hamid, A. Anti-obesity and antioxidant activities of selected medicinal plants and phytochemical profiling of bioactive compounds. Int. J. Food Prop. 2017, 20, 2616-2629. [CrossRef]

6. Torres-Fuentes, C.; Schellekens, H.; Dinan, T.G.; Cryan, J.F. A natural solution for obesity: Bioactives for the prevention and treatment of weight gain. A review. Nutr. Neurosci. 2015, 18, 49-65. [CrossRef] [PubMed]

7. Pan, M.H.; Tung, Y.C.; Yang, G.; Li, S.; Ho, C.T. Molecular mechanisms of the anti-obesity effect of bioactive compounds in tea and coffee. Food Funct. 2016, 7, 4481-4491. [CrossRef] 
8. Kao, E.S.; Yang, M.Y.; Hung, C.H.; Huang, C.N.; Wang, C.J. Polyphenolic extract from Hibiscus sabdariffa reduces body fat by inhibiting hepatic lipogenesis and preadipocyte adipogenesis. Food Funct. 2016, 7, 171-182. [CrossRef]

9. Alarcon-Aguilar, F.J.; Zamilpa, A.; Perez-Garcia, M.D.; Almanza-Perez, J.C.; Romero-Nunez, E.; Campos-Sepulveda, E.A.; Vazquez-Carrillo, L.I.; Roman-Ramos, R. Effect of Hibiscus sabdariffa on obesity in MSG mice. J. Ethnopharmacol. 2007, 114, 66-71. [CrossRef]

10. Kim, J.K.; So, H.; Youn, M.J.; Kim, H.J.; Kim, Y.; Park, C.; Kim, S.J.; Ha, Y.A.; Chai, K.Y.; Kim, S.M.; et al. Hibiscus sabdariffa L. water extract inhibits the adipocyte differentiation through the PI3-K and MAPK pathway. J. Ethnopharmacol. 2007, 114, 260-267. [CrossRef]

11. Huang, T.W.; Chang, C.L.; Kao, E.S.; Lin, J.H. Effect of Hibiscus sabdariffa extract on high fat diet-induced obesity and liver damage in hamsters. Food Nutr. Res. 2015, 59, 29018. [CrossRef]

12. Carvajal-Zarrabal, O.; Hayward-Jones, P.M.; Orta-Flores, Z.; Nolasco-Hipolito, C.; Barradas-Dermitz, D.M.; Aguilar-Uscanga, M.G.; Pedroza-Hernandez, M.F. Effect of Hibiscus sabdariffa L. dried calyx ethanol extract on fat absorption-excretion and body weight implication in rats. J. Biomed. Biotechnol. 2009, 2009, 394592. [CrossRef] [PubMed]

13. Ali, B.H.; Cahlikova, L.; Opletal, L.; Karaca, T.; Manoj, P.; Ramkumar, A.; Al Suleimani, Y.M.; Al Za'abi, M.; Nemmar, A.; Chocholousova-Havlikova, L.; Locarek, M.; Siatka, T.; Blunden, G. Effect of aqueous extract and anthocyanins of calyces of Hibiscus sabdariffa (Malvaceae) in rats with adenine-induced chronic kidney disease. J. Pharm. Pharmacol. 2017, 69, 1219-1229. [CrossRef]

14. Lin, H.H.; Chen, J.H.; Wang, C.J. Chemopreventive properties and molecular mechanisms of the bioactive compounds in Hibiscus sabdariffa Linne. Curr. Med. Chem. 2011, 18, 1245-1254. [CrossRef] [PubMed]

15. Da-Costa-Rocha, I.; Bonnlaender, B.; Sievers, H.; Pischel, I.; Heinrich, M. Hibiscus sabdariffa L.-A phytochemical and pharmacological review. Food Chem. 2014, 165, 424-443. [CrossRef] [PubMed]

16. Moyano, G.; Sáyago-Ayerdi, S.G.; Largo, C.; Caz, V.; Santamaria, M.; Tabernero, M. Potential use of dietary fibre from Hibiscus sabdariffa and Agave tequilana in obesity management. J. Funct. Food 2016, 21, 1-9. [CrossRef]

17. Riaz, G.; Chopra, R. A review on phytochemistry and therapeutic uses of Hibiscus sabdariffa L. Biomed. Pharmacother. 2018, 102, 575-586. [CrossRef] [PubMed]

18. He, J.; Giusti, M.M. Anthocyanins: Natural colorants with health-promoting properties. Annu. Rev. Food Sci. Tech. 2010, 1, 163-187. [CrossRef]

19. Wang, L.-S.; Stoner, G.D. Anthocyanins and their role in cancer prevention. Cancer Lett. 2008, 269, $281-290$. [CrossRef]

20. Perez-Torres, I.; Ruiz-Ramirez, A.; Banos, G.; El-Hafidi, M. Hibiscus sabdariffa Linnaeus (Malvaceae), curcumin and resveratrol as alternative medicinal agents against metabolic syndrome. Cardiovasc. Hematol. Agents Med. Chem. 2013, 11, 25-37. [CrossRef]

21. Tseng, T.H.; Kao, T.W.; Chu, C.Y.; Chou, F.P.; Lin, W.L.; Wang, C.J. Induction of apoptosis by hibiscus protocatechuic acid in human leukemia cells via reduction of retinoblastoma (RB) phosphorylation and Bcl-2 expression. Biochem. Pharmacol. 2000, 60, 307-315. [CrossRef]

22. Darwish, R.M.; Aburjai, T.; Al-Khalil, S.; Mahafzah, A. Screening of antibiotic resistant inhibitors from local plant materials against two different strains of Staphylococcus aureus. J Ethnopharmacol. 2002, 79, 359-364. [CrossRef]

23. Amos, S.; Binda, L.; Chindo, B.; Tseja, A.; Odutola, A.; Wambebe, C.; Gamaniel, K. Neuropharmacological effects of Hibiscus sabdariffa aqueous extract. Pharm. Biol. 2003, 41, 325-329. [CrossRef]

24. Odigie, I.P.; Ettarh, R.R.; Adigun, S.A. Chronic administration of aqueous extract of Hibiscus sabdariffa attenuates hypertension and reverses cardiac hypertrophy in $2 \mathrm{~K}-1 \mathrm{C}$ hypertensive rats. J. Ethnopharmacol. 2003, 86, 181-185. [CrossRef]

25. Herrera-Arellano, A.; Miranda-Sanchez, J.; Avila-Castro, P.; Herrera-Alvarez, S.; Jimenez-Ferrer, J.E.; Zamilpa, A.; Roman-Ramos, R.; Ponce-Monter, H.; Tortoriello, J. Clinical effects produced by a standardized herbal medicinal product of Hibiscus sabdariffa on patients with hypertension. A randomized, double-blind, lisinopril-controlled clinical trial. Planta Med. 2007, 73, 6-12. [CrossRef] [PubMed]

26. Hirunpanich, V.; Utaipat, A.; Morales, N.P.; Bunyapraphatsara, N.; Sato, H.; Herunsale, A.; Suthisisang, C. Hypocholesterolemic and antioxidant effects of aqueous extracts from the dried calyx of Hibiscus sabdariffa L. in hypercholesterolemic rats. J. Ethnopharmacol. 2006, 103, 252-260. [CrossRef] 
27. Ali, B.H.; Wabel, N.A.; Blunden, G. Phytochemical, pharmacological and toxicological aspects of Hibiscus sabdariffa L.: A review. Phytother. Res. 2005, 19, 369-375. [CrossRef] [PubMed]

28. Mungole, A.; Chaturvedi, A. Hibiscus sabdariffa L a rich source of secondary metabolites. Int. J. Pharm. Sci. Rev. Res. 2011, 6, 83-87.

29. Wahabi, H.A.; Alansary, L.A.; Al-Sabban, A.H.; Glasziuo, P. The effectiveness of Hibiscus sabdariffa in the treatment of hypertension: A systematic review. Phytomedicine 2010, 17, 83-86. [CrossRef]

30. Carvajal-Zarrabal, O.; Barradas-Dermitz, D.M.; Orta-Flores, Z.; Hayward-Jones, P.M.; Nolasco-Hipólito, C.; Aguilar-Uscanga, M.G.; Miranda-Medina, A.; Bujang, K.B. Hibiscus sabdariffa L., roselle calyx, from ethnobotany to pharmacology. J Exp. Pharm. 2012, 4, 25. [CrossRef]

31. Hopkins, A.L.; Lamm, M.G.; Funk, J.L.; Ritenbaugh, C. Hibiscus sabdariffa L. in the treatment of hypertension and hyperlipidemia: A comprehensive review of animal and human studies. Fitoterapia 2013, 85, 84-94. [CrossRef]

32. Serban, C.; Sahebkar, A.; Ursoniu, S.; Andrica, F.; Banach, M. Effect of sour tea (Hibiscus sabdariffa L.) on arterial hypertension: A systematic review and meta-analysis of randomized controlled trials. J. Hypertens. 2015, 33, 1119-1127. [CrossRef]

33. Walton, R.J.; Whitten, D.L.; Hawrelak, J.A. The efficacy of Hibiscus sabdariffa (rosella) in essential hypertension: A systematic review of clinical trials. Aust. J. Herb. Med. 2016, 28, 48.

34. Singh, P.; Khan, M.; Hailemariam, H. Nutritional and Health Importance of Hibiscus Sabdariffa: A Review and Indication for Research Needs. J. Nutr. Health Food Eng. 2017, 6, 1-4.

35. Ismail, A.; Ikram, E.H.K.; Nazri, H.S.M. Roselle (Hibiscus sabdariffa L.) seeds-nutritional composition, protein quality and health benefits. Food 2008, 2, 1-16.

36. Herranz-Lopez, M.; Olivares-Vicente, M.; Encinar, J.A.; Barrajon-Catalan, E.; Segura-Carretero, A.; Joven, J.; Micol, V. Multi-Targeted Molecular Effects of Hibiscus sabdariffa Polyphenols: An Opportunity for a Global Approach to Obesity. Nutrients 2017, 9, 907. [CrossRef] [PubMed]

37. Aziz, Z.; Wong, S.Y.; Chong, N.J. Effects of Hibiscus sabdariffa L. on serum lipids: A systematic review and meta-analysis. J. Ethnopharmacol. 2013, 150, 442-450. [CrossRef] [PubMed]

38. Bernhoft, A.; Siem, H.; Bjertness, E.; Meltzer, M.; Flaten, T.; Holmsen, E. Bioactive compounds in plants-benefits and risks for man and animals. In Proceedings of the Symposium Held at The Norwegian Academy of Science and Letters, Oslo, Norway, 13-14 November 2008.

39. Kumar, G.; Sharmila Banu, G.; Murugesan, A.G. Attenuation of Helicteres isora L. bark extracts on streptozotocin-induced alterations in glycogen and carbohydrate metabolism in albino rats. Hum. Exp. Toxicol. 2009, 28, 689-696. [CrossRef] [PubMed]

40. Ganesan, K.; Ramasamy, M.; Gani, S.B. Antihyperlipideamic effect of Solanum trilobatum L. leaves extract on streptozotocin induced diabetic rats. Asian J. Biomed. Pharm. Sci. 2013, 3, 51-56.

41. Igho, O.; Kang, H.S.; Rachel, P.; Barbara, W.; Edzard, E. The use of Garcinia extract (hydroxycitric acid) as a weight loss supplement: A systematic review and meta-analysis of randomised clinical trials. J. Obes. 2010, 2011, 1-9.

42. Heymsfield, S.B.; Allison, D.B.; Vasselli, J.R.; Pietrobelli, A.; Greenfield, D.; Nunez, C. Garcinia cambogia (hydroxycitric acid) as a potential antiobesity agent: A randomized controlled trial. Jama 1998, 280, 1596-1600. [CrossRef]

43. Parra-Vargas, M.; Sandoval-Rodriguez, A.; Rodriguez-Echevarria, R.; Dominguez-Rosales, J.; Santos-Garcia, A.; Armendariz-Borunda, J. Delphinidin ameliorates hepatic triglyceride accumulation in human HepG2 cells, but not in diet-induced obese mice. Nutrients 2018, 10, 1060. [CrossRef] [PubMed]

44. Ahn, J.; Lee, H.; Kim, S.; Park, J.; Ha, T. The anti-obesity effect of quercetin is mediated by the AMPK and MAPK signaling pathways. Biochem. Biophy. Res. Commun. 2008, 373, 545-549. [CrossRef] [PubMed]

45. Rivera, L.; Morón, R.; Sánchez, M.; Zarzuelo, A.; Galisteo, M. Quercetin ameliorates metabolic syndrome and improves the inflammatory status in obese Zucker rats. Obesity 2008, 16, 2081-2087. [CrossRef] [PubMed]

46. Kwon, E.-Y.; Jung, U.J.; Park, T.; Yun, J.W.; Choi, M.-S. Luteolin attenuates hepatic steatosis and insulin resistance through the interplay between the liver and adipose tissue in mice with diet-induced obesity. Diabetes 2015, 64, 1658-1669. [CrossRef]

47. Cho, A.-S.; Jeon, S.-M.; Kim, M.-J.; Yeo, J.; Seo, K.-I.; Choi, M.-S.; Lee, M.-K. Chlorogenic acid exhibits anti-obesity property and improves lipid metabolism in high-fat diet-induced-obese mice. Food Chem. Toxicol. 2010, 48, 937-943. [CrossRef] [PubMed] 
48. Thom, E. The effect of chlorogenic acid enriched coffee on glucose absorption in healthy volunteers and its effect on body mass when used long-term in overweight and obese people. J. Int. Med. Res. 2007, 35, 900-908. [CrossRef] [PubMed]

49. Scazzocchio, B.; Varì, R.; Filesi, C.; D’archivio, M.; Santangelo, C.; Giovannini, C.; Iacovelli, A.; Silecchia, G.; Volti, G.L.; Galvano, F. Cyanidin-3-O- $\beta$-glucoside and protocatechuic acid exert insulin-like effects by upregulating PPAR $\gamma$ activity in human omental adipocytes. Diabetes 2011, DB_101461. [CrossRef]

50. Yoshimura, Y.; Nishii, S.; Zaima, N.; Moriyama, T.; Kawamura, Y. Ellagic acid improves hepatic steatosis and serum lipid composition through reduction of serum resistin levels and transcriptional activation of hepatic ppara in obese, diabetic KK-Ay mice. Biochem. Biophy. Res. Commun. 2013, 434, 486-491. [CrossRef]

51. Panchal, S.K.; Ward, L.; Brown, L. Ellagic acid attenuates high-carbohydrate, high-fat diet-induced metabolic syndrome in rats. Eur. J. Nutr. 2013, 52, 559-568. [CrossRef]

52. Kang, S.-W.; Kang, S.-I.; Shin, H.-S.; Yoon, S.-A.; Kim, J.-H.; Ko, H.-C.; Kim, S.-J. Sasa quelpaertensis Nakai extract and its constituent p-coumaric acid inhibit adipogenesis in 3T3-L1 cells through activation of the AMPK pathway. Food Chem. Toxicol. 2013, 59, 380-385. [CrossRef]

53. Son, M.J.; Rico, C.W.; Nam, S.H.; Kang, M.Y. Influence of oryzanol and ferulic acid on the lipid metabolism and antioxidative status in high fat-fed mice. J. Clin. Biochem. Nutr. 2010, 46, 150-156. [CrossRef] [PubMed]

54. Naowaboot, J.; Piyabhan, P.; Munkong, N.; Parklak, W.; Pannangpetch, P. Ferulic acid improves lipid and glucose homeostasis in high-fat diet-induced obese mice. Clin. Exp. Pharm. Phy. 2016, 43, 242-250. [CrossRef] [PubMed]

55. Liao, C.-C.; Ou, T.-T.; Wu, C.-H.; Wang, C.-J. Prevention of diet-induced hyperlipidemia and obesity by caffeic acid in C57BL/ 6 mice through regulation of hepatic lipogenesis gene expression. J. Agric. Food Chem. 2013, 61, 11082-11088. [CrossRef] [PubMed]

56. Juman, S.; Yasui, N.; Okuda, H.; Ueda, A.; Negishi, H.; Miki, T.; Ikeda, K. Caffeic acid phenethyl ester suppresses the production of adipocytokines, leptin, tumor necrosis factor-alpha and resistin, during differentiation to adipocytes in 3T3-L1 cells. Biol. Pharm. Bull. 2011, 34, 490-494. [CrossRef] [PubMed]

57. Morales-Luna, E.; Perez-Ramirez, I.F.; Salgado, L.M.; Castano-Tostado, E.; Gomez-Aldapa, C.A.; Reynoso-Camacho, R. The main beneficial effect of roselle (Hibiscus sabdariffa) on obesity is not only related to its anthocyanin content. J. Sci. Food Agric. 2018, 99, 596-605. [CrossRef]

58. Herranz-Lopez, M.; Fernandez-Arroyo, S.; Perez-Sanchez, A.; Barrajon-Catalan, E.; Beltran-Debon, R.; Menendez, J.A.; Alonso-Villaverde, C.; Segura-Carretero, A.; Joven, J.; Micol, V. Synergism of plant-derived polyphenols in adipogenesis: Perspectives and implications. Phytomedicine 2012, 19, 253-261. [CrossRef] [PubMed]

59. Sinela, A.; Rawat, N.; Mertz, C.; Achir, N.; Fulcrand, H.; Dornier, M. Anthocyanins degradation during storage of Hibiscus sabdariffa extract and evolution of its degradation products. Food Chem. 2017, 214, 234-241. [CrossRef]

60. Jabeur, I.; Pereira, E.; Barros, L.; Calhelha, R.C.; Soković, M.; Oliveira, M.B.P.; Ferreira, I.C. Hibiscus sabdariffa L. as a source of nutrients, bioactive compounds and colouring agents. Food Res. Int. 2017, 100, 717-723. [CrossRef]

61. Villalpando-Arteaga, E.V.; Mendieta-Condado, E.; Esquivel-Solis, H.; Canales-Aguirre, A.A.; Galvez-Gastelum, F.J.; Mateos-Diaz, J.C.; Rodriguez-Gonzalez, J.A.; Marquez-Aguirre, A.L. Hibiscus sabdariffa L. aqueous extract attenuates hepatic steatosis through down-regulation of PPAR-gamma and SREBP-1c in diet-induced obese mice. Food Funct. 2013, 4, 618-626. [CrossRef]

62. Peng, C.H.; Chyau, C.C.; Chan, K.C.; Chan, T.H.; Wang, C.J.; Huang, C.N. Hibiscus sabdariffa polyphenolic extract inhibits hyperglycemia, hyperlipidemia, and glycation-oxidative stress while improving insulin resistance. J. Agric. Food Chem. 2011, 59, 9901-9909. [CrossRef]

63. Yang, Y.-S.; Huang, C.-N.; Wang, C.-J.; Lee, Y.-J.; Chen, M.-L.; Peng, C.-H. Polyphenols of Hibiscus sabdariffa improved diabetic nephropathy via regulating the pathogenic markers and kidney functions of type 2 diabetic rats. J. Funct. Food 2013, 5, 810-819. [CrossRef]

64. Si, L.Y.-N.; Ali, S.A.M.; Latip, J.; Fauzi, N.M.; Budin, S.B.; Zainalabidin, S. Roselle is cardioprotective in diet-induced obesity rat model with myocardial infarction. Life Sci. 2017, 191, 157-165. [CrossRef] [PubMed]

65. Ibrahim, K.G.; Chivandi, E.; Mojiminiyi, F.B.O.; Erlwanger, K.H. The response of male and female rats to a high-fructose diet during adolescence following early administration of Hibiscus sabdariffa aqueous calyx extracts. J. Dev. Orig. Hlth. Dis. 2017, 8, 628-637. [CrossRef] [PubMed] 
66. Chang, H.C.; Peng, C.H.; Yeh, D.M.; Kao, E.S.; Wang, C.J. Hibiscus sabdariffa extract inhibits obesity and fat accumulation, and improves liver steatosis in humans. Food Funct. 2014, 5, 734-739. [CrossRef] [PubMed]

67. Gurrola-Diaz, C.M.; Garcia-Lopez, P.M.; Sanchez-Enriquez, S.; Troyo-Sanroman, R.; Andrade-Gonzalez, I.; Gomez-Leyva, J.F. Effects of Hibiscus sabdariffa extract powder and preventive treatment (diet) on the lipid profiles of patients with metabolic syndrome (MeSy). Phytomedicine 2010, 17, 500-505. [CrossRef] [PubMed]

68. Kim, M.S.; Kim, J.K.; Kim, H.J.; Moon, S.R.; Shin, B.C.; Park, K.W.; Yang, H.O.; Kim, S.M.; Park, R. Hibiscus extract inhibits the lipid droplet accumulation and adipogenic transcription factors expression of 3T3-L1 preadipocytes. J. Altern. Complem. Med. 2003, 9, 499-504. [CrossRef]

69. Kopelman, P.G. Obesity as a medical problem. Nature 2000, 404, 635-643. [CrossRef]

70. Xiao, P.; Yang, Z.; Sun, J.; Tian, J.; Chang, Z.; Li, X.; Zhang, B.; Ye, Y.; Ji, H.; Yu, E.; Xie, J. Silymarin inhibits adipogenesis in the adipocytes in grass carp Ctenopharyngodon idellus in vitro and in vivo. Fish Physiol. Biochem. 2017, 43, 1487-1500. [CrossRef]

71. Akindahunsi, A.A.; Olaleye, M.T. Toxicological investigation of aqueous-methanolic extract of the calyces of Hibiscus sabdariffa L. J. Ethnopharmacol. 2003, 89, 161-164. [CrossRef]

72. Hansawasdi, C.; Kawabata, J.; Kasai, T. $\alpha$-Amylase inhibitors from roselle (Hibiscus sabdariffa Linn.) tea. Biosci. Biotech. Biochem. 2000, 64, 1041-1043. [CrossRef]

73. Preuss, H.G.; Echard, B.; Bagchi, D.; Stohs, S. Inhibition by natural dietary substances of gastrointestinal absorption of starch and sucrose in rats and pigs: 1. Acute studies. Int. J. Med. Sci. 2007, 4, 196. [CrossRef] [PubMed]

74. Ofei, F. Obesity-a preventable disease. Ghana Med. J. 2005, 39, 98-101.

75. Crosignani, A.; Zuin, M.; Allocca, M.; Del Puppo, M. Oxysterols in bile acid metabolism. Clin. Chim. Acta 2011, 412, 2037-2045. [CrossRef] [PubMed]

76. Liu, J.Y.; Chen, C.C.; Wang, W.H.; Hsu, J.D.; Yang, M.Y.; Wang, C.J. The protective effects of Hibiscus sabdariffa extract on CCl4-induced liver fibrosis in rats. Food Chem. Toxicol. 2006, 44, 336-343. [CrossRef]

77. Hursel, R.; Westerterp-Plantenga, M.S. Thermogenic ingredients and body weight regulation. Int. J. Obes. 2010, 34, 659-669. [CrossRef] [PubMed]

78. Sun, N.N.; Wu, T.Y.; Chau, C.F. Natural Dietary and Herbal Products in Anti-Obesity Treatment. Molecules 2016, 21, 1351. [CrossRef] [PubMed]

79. Marrelli, M.; Loizzo, M.R.; Nicoletti, M.; Menichini, F.; Conforti, F. Inhibition of key enzymes linked to obesity by preparations from Mediterranean dietary plants: Effects on $\alpha$-amylase and pancreatic lipase activities. Plant Food Hum. Nutr. 2013, 68, 340-346. [CrossRef]

80. Heck, A.M.; Yanovski, J.A.; Calis, K.A. Orlistat, a new lipase inhibitor for the management of obesity. Pharmacotherapy 2000, 20, 270-279. [CrossRef]

81. Farmer, S.R. Regulation of PPARgamma activity during adipogenesis. Int. J. Obes. 2005, 29, S13-S16. [CrossRef]

82. Birbrair, A.; Zhang, T.; Wang, Z.M.; Messi, M.L.; Enikolopov, G.N.; Mintz, A.; Delbono, O. Role of pericytes in skeletal muscle regeneration and fat accumulation. Stem Cell Dev. 2013, 22, 2298-2314. [CrossRef] [PubMed]

83. Fasshauer, M.; Bluher, M. Adipokines in health and disease. Trends Pharmacol. Sci. 2015, 36, 461-470. [CrossRef] [PubMed]

84. Lei, F.; Zhang, X.N.; Wang, W.; Xing, D.M.; Xie, W.D.; Su, H.; Du, L.J. Evidence of anti-obesity effects of the pomegranate leaf extract in high-fat diet induced obese mice. Int. J. Obes. 2007, 31, 1023-1029. [CrossRef] [PubMed]

85. Rosen, E.D. The transcriptional basis of adipocyte development. Prostag. Leukotr. Ess. 2005, 73, 31-34. [CrossRef]

86. Murase, Y.; Kobayashi, J.; Nohara, A.; Asano, A.; Yamaaki, N.; Suzuki, K.; Sato, H.; Mabuchi, H. Raloxifene promotes adipocyte differentiation of 3T3-L1 cells. Eur. J. Pharm. 2006, 538, 1-4. [CrossRef]

87. Wagatsuma, A. Upregulation of gene encoding adipogenic transcriptional factors $\mathrm{C} / \mathrm{EBP} \alpha$ and PPAR $\gamma 2$ in denervated muscle. Exp. Physiol. 2006, 91, 747-753. [CrossRef] [PubMed]

88. Gosmann, G.; Barlette, A.G.; Dhamer, T.; Arcari, D.P.; Santos, J.C.; de Camargo, E.R.; Acedo, S.; Gambero, A.; Gnoatto, S.C.; Ribeiro, M.L. Phenolic compounds from mate (Ilex paraguariensis) inhibit adipogenesis in 3T3-L1 preadipocytes. Plant Food Hum. Nutr. 2012, 67, 156-161. [CrossRef] [PubMed] 
89. Min, S.Y.; Yang, H.; Seo, S.G.; Shin, S.H.; Chung, M.Y.; Kim, J.; Lee, S.J.; Lee, H.J.; Lee, K.W. Cocoa polyphenols suppress adipogenesis in vitro and obesity in vivo by targeting insulin receptor. Int. J. Obes. 2013, 37, 584-592. [CrossRef]

90. Kim, J.S.; Lee, S.G.; Kang, Y.J.; Kwon, T.K.; Nam, J.O. Kahweol inhibits adipogenesis of 3T3-L1 adipocytes through downregulation of PPARgamma. Nat. Prod. Res. 2018, 32, 1216-1219. [CrossRef]

91. Lee, S.G.; Kim, J.S.; Min, K.; Kwon, T.K.; Nam, J.O. Hispidulin inhibits adipogenesis in 3T3-L1 adipocytes through PPARgamma pathway. Chem. Biol. Interact. 2018, 293, 89-93. [CrossRef]

92. Onyenekwe, P.; Ajani, E.; Ameh, D.; Gamaniel, K. Antihypertensive effect of roselle (Hibiscus sabdariffa) calyx infusion in spontaneously hypertensive rats and a comparison of its toxicity with that in Wistar rats. Cell Biochem. Funct. 1999, 17, 199-206. [CrossRef]

93. Orisakwe, O.E.; Husaini, D.C.; Afonne, O.J. Testicular effects of sub-chronic administration of Hibiscus sabdariffa calyx aqueous extract in rats. Reprod. Toxicol. 2004, 18, 295-298. [CrossRef] [PubMed]

94. Ndu, O.O.; Nworu, C.S.; Ehiemere, C.O.; Ndukwe, N.C.; Ochiogu, I.S. Herb-drug interaction between the extract of Hibiscus sabdariffa L. and hydrochlorothiazide in experimental animals. J. Med. Food 2011, 14, 640-644. [CrossRef] [PubMed]

95. Kolawole, J.; Maduenyi, A. Effect of zobo drink (Hibiscus sabdariffa water extract) on the pharmacokinetics of acetaminophen in human volunteers. Eur. J. Drug Metab. Pharmacok. 2004, 29, 25-29. [CrossRef]

96. Khaghani, S.; Razi, F.; Yajloo, M.M.; Paknejad, M.; Shariftabrizi, A.; Pasalar, P. Selective cytotoxicity and apoptogenic activity of Hibiscus sabdariffa aqueous extract against MCF-7 human breast cancer cell line. J. Cancer Ther. 2011, 2, 394. [CrossRef]

97. Fakeye, T.O.; Pal, A.; Bawankule, D.; Yadav, N.; Khanuja, S. Toxic effects of oral administration of extracts of dried calyx of Hibiscus sabdariffa Linn.(Malvaceae). Phytother. Res. 2009, 23, 412-416. [CrossRef] [PubMed]

(C) 2019 by the authors. Licensee MDPI, Basel, Switzerland. This article is an open access article distributed under the terms and conditions of the Creative Commons Attribution (CC BY) license (http:/ / creativecommons.org/licenses/by/4.0/). 